\title{
Editorial
}

\section{Sébastien Billioud}

\section{(2) OpenEdition}

Journals

Édition électronique

URL : http://journals.openedition.org/chinaperspectives/3203

DOI : 10.4000/chinaperspectives.3203

ISSN : 1996-4617

\section{Éditeur}

Centre d'étude français sur la Chine contemporaine

\section{Édition imprimée}

Date de publication : 1 janvier 2008

Pagination : 1-1

ISSN : 2070-3449

\section{Référence électronique}

Sébastien Billioud, «Editorial », China Perspectives [En ligne], 2008/1 | 2008, mis en ligne le 01 janvier 2008, consulté le 24 septembre 2020. URL : http://journals.openedition.org/chinaperspectives/3203 ; DOI : https://doi.org/10.4000/chinaperspectives.3203 


\section{Editorial}

7 he approaching Beijing Games, the eventful Olympic Torch relay, and the robust reactions it sparked among Chinese people around the world, are among the current developments highlighting the relationship between sports and politics. This theme is the focus of this issue of China Perspectives, which includes a series of articles that do not directly address recent events but nevertheless offer insights for understanding them.

The issue opens with an article by Dong-Jhy Hwang and Li-Ke Chang that provides a retrospective on the development of sports in China since the establishment of the People's Republic. Among the topics it touches on are the Great Helmsman's thoughts on physical culture, the absolute primacy of politics in sports during the Cultural Revolution, and the subtler role of politics in the reform era. Xu Guoqi follows with a well-documented analysis of China's participation in the 1952 Helsinki Games, tracing the Olympic movement's importance to the respective strategies of Beijing and Taipei to achieve international diplomatic recognition, and highlighting the enduring and eminently political dimension of the Games in the eyes of the Chinese authorities. Gladys Chicharro-Saito, for her part, explores the relationship between sports and politics through a local prism. Based on fieldwork in Hebei Province, she analyses the manner in which physical education is used as a vector to inculcate moral values in elementary schools. Finally, Séverine Bardon's contribution shows how the Chinese athlete training system is gradually moving beyond political imperatives of national prestige and being absorbed into a full-scalled sports industry. Aurélien Boucher provides an additional perspective in a research note on the introduction of sports to China.

Apart from this dossier, the issue contains a selection of articles and review essays. China Perspectives previously carried relatively brief accounts of recent books, but we shall henceforth also host longer reflections. Tibet is the focus of some of the review essays that you will discover in this issue.

Good reading,

\section{Sébastien Billioud}

